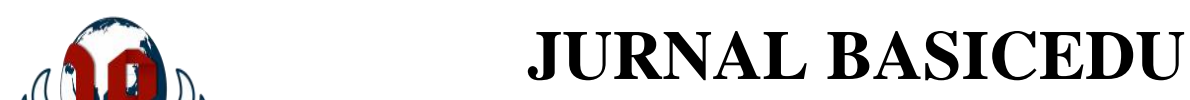

Volume 5 Nomor 4 Tahun 2021 Halaman 2045 - 2053

Research \& Learning in Elementary Education

https://jbasic.org/index.php/basicedu

PAHLAWAN

\title{
Analisis Implementasi Karakter Mandiri Siswa Sekolah Dasar di Masa Pandemi Covid-19 Berbasis Media Asinkronus
}

\author{
Tera Noviantiningtyas Ripto Saputri ${ }^{1 凶}$, Bagus Amirul Mukmin ${ }^{2}$ \\ Universitas Nusantara PGRI Kediri, Indonesia ${ }^{1,2}$ \\ E-mail: teranovianti114@gmail.com ${ }^{1}$, bagusamirulm@ gmail.com ${ }^{2}$
}

\begin{abstract}
Abstrak
Penelitian ini menggunakan media berbasis asinkronus untuk sebagai media pendukung untuk siswa SDN Mojoroto 4 Kota Kediri untuk pengumpulan tugas dengan didampingi orang tua. Tujuan dari penelitian ini yaitu menganalisis karakter mandiri siswa di masa pandemi Covid-19 dengan menggunakan media asinkronus amaka dapat dijadikan pedoman untuk mengetahui karakter siswa langsung dari orang tuannya sehingga guru dapat bekerjasama orang tuanya secara langsung. Metode penelitian ini adalah deskriptif kuantitatif dengan subjek penelitian yaitu kelas IV A terdiri dari 15 siswa, 7 siswa laki-laki dan 8 siswa perempuan. Hasil penelitian ini selama pembelajaran daring banyak dominan siswa sangat tanggung jawab terhadap pembelajaran dan banyak siswa tepat waktu dalam mengumpulkan sebanyak 9 orang atau $60 \%$, siswa yang selalu semangat ikut pembelajaran sebanyak $10 \%$ atau 66,6\%, lebih dominan kriteria siswa rajin sebnayak $14 \%$ atau 93,3\%, kemudian siswa yang terkadang mampu membuat karya mandiri banyak dibimbing orang tua dalam mengerjakan sebanyak 11 orang atau $73,3 \%$, siswa terkadang bertanya saat pembelajaran sebanyak 10 orang siswa atau $66,6 \%$, kemudian siswa y terkadang minta bimbingan orang tua atau orang lain dalam mengerjakan sebanyak 11 orang atau 73,3\%, dan siswa yang terkadang belajar sebanyak siswa 8 orang atau $53,3 \%$.
\end{abstract}

Kata Kunci: Karakter, mandiri, media Asinkronus.

\section{Abstract}

This study uses asynchronous-based media as a supporting medium for students of SDN Mojoroto 4 Kediri City to collect assignments accompanied by parents. The purpose of this study is to analyze the independent character of students during the Covid-19 pandemic using asynchronous media so that it can be used as a guide to determine the character of students directly from their parents so that teachers can work with their parents directly. This research method is descriptive quantitative with research subjects namely class IV A consisting of 15 students, 7 male students and 8 female students. The results of this study during online learning that many students are very responsible for learning and many students are on time in collecting as many as 9 people or $60 \%$, students who are always enthusiastic about participating in learning are $10 \%$ or $66.6 \%$, more dominant criteria are students who are diligent as many as $14 \%$ or $93.3 \%$, then students who are sometimes able to make independent work are often guided by their parents in doing as many as 11 people or $73.3 \%$, students sometimes ask 10 students or $66.6 \%$ when learning, then student y sometimes asks guidance from parents or other people in doing work as many as 11 people or $73.3 \%$, and students who sometimes study as many as 8 students or $53.3 \%$.

Keywords: Character, standalone, Asynchronous media

Copyright (c) 2021 Tera Noviantiningtyas Ripto Saputri, Bagus Amirul Mukmin

Corresponding author :

Email : teranovianti114@gmail.com

DOI : https://doi.org/10.31004/basicedu.v5i4.1126

ISSN 2580-3735 (Media Cetak)

ISSN 2580-1147 (Media Online) 


\section{PENDAHULUAN}

Pendidikan merupakan hal penting dalam hidup dengan pemberian materi, pemberian pengetahuan, pemberian kebenaran dalam melakukan sesuatu, dll. Menurut Syah dan Rini mengatakan bahwa pendidikan mempunyai pengertian melakukan latihan dan pemeliharaan dimana keduanya memerlukan suatu bimbingan baik kecerdasan pikiran ataupun perilaku. Dengan diperkuat pernyataan tersebut dapat dikatakan bahwa pendidikan harus adanya sebuah pelatihan dan bimbingan yang bertujuan untuk memberikan pendidikan yang utuh. Dengan adanya pendidikan kualitas hidup kita akan menjadi meningkat. Dengan yang awal tidak tahu menjadi tahu dan yang awal sudah tau akan menjadi lebih tahu. Tidak ada salahnya kita terus belajar untuk meningkatkan kualitas hidup dalam menghadapi tantangan selanjutnya. Dunia pendidikan selalu identik dengan adanya pembelajaran. Banyak sekali hal yang dipelajari dan diajarkan oleh guru. Di dalam pembelajaran selain tingkat pengetahuan yang dinilai maka ada banyak faktor lain yang dinilai seperti karakter siswa.

Karakter siswa dapat dilihat dan diamati melalui kegiatan sehari-hari ketika melaksanakan pembelajaran. Diperkuat dengan pernyataan (Sakti, 2018) pendidikan karakter yang dilaksanakan di sekolah untuk dijadikan pengembangan dalam karakter untuk menjadi karakter yang baik. Diperkuat dengan (Faqih, 2019) Pendidikan karakter dibiasakan dari proses pembelajaran guna untuk tetap membiasakan dan melakukan pengembangan dalam karakter. Saat ini banyak peserta didik yang tinggi dalam prestasinya namun dalam karakternya rendah apalagi di zaman sekarang. Ada banyak beberapa indikator dalam karakter siswa seperti karakter religious, mandiri, nasionalis, dll. Diperkuat menurut kemendikbud dalam (Oviana, 2020) bahwa karakter siswa terdiri dari 5 yaitu religious, nasionalis, mandiri, gotong royong, integritas. Karakter siswa dapat dilihat secara langsung. Oleh sebab itu, terdapat kendala dan tantangan sendiri apabila dalam mengamati karakter dilihat atau dipantau dari jarak jauh, apalagi saat adanya pandemik yang harus melakukan kegiatan dari rumah.

Seperti yang kita tahu pada tahun 2019 terdapat virus yang memberikan dampak yang signifikan dalam memberikan perubahan tak terkecuali dalam dunia pendidikan. Pandemi memberikan tantangan tersendiri bagi pendidik yang ada diseluruh dunia. Baik di mulai dari sekolah dasar maupun anak usia dini maupun dalam perkuliahan. Banyak perlakuan dan inovasi yang diberikan untuk menstabilkan kualitas pendidikan. Untuk itu pemerintah memutuskan dengan melakukan pembelajran melalui pembelajaran daring. Menurut (Sadikin \& Hamidah, 2020) bahwa bentuk pembelajaran di masa pandemi dapat dilakukan dengan pembelajaran daring. Pembelajaran daring yang menggunakan bantuan teknologi tanpa adanya pertemuan secara langsung. Menurut (Handarini \& Wulandari, 2020) menyatakan bahwa pembelajaran daring adalah pembelajaran yang terjadi dengan tidak dilakukannya pertemuan secara langsung tapi menggunakan media khusus untuk melaksanakan proses pembelajaran walaupun tidak dilakukan dengan tatap muka.

Pembelajaran daring disebut juga dengan pembelajaran online. Menurut (Arsyad, 2011) media pembelajaran yang dilaksanakan secara online atau nama lainnya yaitu e-learning yang memberikan pengganti pada proses pembelajaran yang dilaksanakan secara langsung, sehingga pembelajaran e-learning dilaksanakan dengan online dengan menggunakan aplikasi online. Banyak aplikasi online yang beredar dapat digunakan dalam dunia pembelajaran. Tak sedikit pula pendidik yang menggunakan aplikasi online di antaranya adalah zoom, Whatsaap, google meet, dll. Konsep pada pembelajaran daring ini adalah dengan terfokuskan pada karakter siswa karena guru hanya sebagai fasilitator. Menurut (Anugrahana, 2020) proses dalam pembelajaran daring atau e-learning yaitu menjadikan guru hanya sebagai fasilitator dan siswa menjadi yang aktif dalam proses pembelajaran. Untuk itu guru harus berusaha menghadapi tantangan untuk membuat pembelajaran daring ini menjadi lebih diminati dan siswa menjadi nyaman serta aktif dalam proses pembelajaran. Khususnya pada penanaman karakter siswa agar tidak menjadi turun meskipun dilakukan 
dengan pembelajaran daring. Keaktifan siswa dapat dilihat melalui karakter mandiri yang ada pada diri siswa. Oleh sebab itu, pada penelitian ini melaksanakan penelitian karakter mandiri terhadap siswa.

Dengan banyaknya aplikasi yang bisa digunakan dalam pembelajaran seharusnya gurupun bisa menggunakannya dengan semaksimal mungkin. Terdapat banyak guru yang menggunakan media asinkronus seperti whatsaap, google classroom, Edmodo, dll. Diperkuat dengan (Daheri et al., 2020) bahwa pada sekolah dasar banyak sekali yang hanya menggunakan aplikasi whatsaap dalam pembelajran bahkan hingga 100\% sekolah dasar yang menggunakan whatsaap. Kita tahu bahwa dalam pembelajaran menggunakan watsaap sulit untuk melihat indikator dalam karakter mandiri siswa karena whatsaap adalah media searah yang digunakan dan sulit untuk secara langsung dalam mengamati karakter siswa. Padahal dalam dunia pendidikan pembentukan dan pelatihan dalam pembentukan karakter adalah hal yang terpenting dengan melihat memonitoring karakter siswa agar selalu terbentuknya pendidikan karakter walaupun saat pembelajaran daring terutama pada sekolah dasar. Diperkuat menurut Nurazkiyah, dkk bahwa kekurangan dalam pembelajaran daring ini yang diajarkan hanya melalui gadget guru tidak dapat memberikan pendidikan karakter secara langsung dan untuk mengetahui keaktifan siswa. Oleh sebab itu, harus adanya kerjasama antara orangtua dan guru dalam pembelajaran secara daring ini untuk dapat membentuk karakter siswa secara maksimal.

Begitu juga SDN Mojoroto 4 Kota Kediri pada kelas IV yang menjadikan whatsaap, google form, google classroom yang dijadikan sebagai ruang pembelajaran terutama dalam pengumpulan tugas. Karakter mandiri siswa yang sebenarnya harus dilihat dalam pembelajaran sehingga menjadi terhambat. Indikator karakter mandiri siswa meliputi bertanggungjawab, tepat waktu dalam mengumpulkan tugas, semangat, rajin, memberikan ide, berani berbicara, belajar, dan mengerjakan tugas mandiri. Aspek penelitian dengan menggunakan media berbasis asinkronus. Alasan dengan memakai media sinkronus karena SDN Mojoroto 4 Kota Kediri ini menggunakan media tersebut untuk dijadikan pengumpulan tugas dengan didampingi orang tua. Media asinkronus adalah media yang berinteraksi secara tidak langsung artinya terbatasnya tempat yang tidak harus bertemunya kedua belah pihak seperti whatsaap, google form, google classroom, Edmodo, email, dll. Diperkuat dengan (Fahmi, 2020) bahwa media asinkronus adalah media yang digunakan antara guru dan murid tidak bertemu secara langsung dalam waktu dan tempat yang sama. Penelitian ini terfokus pada pemebelajaran tematik kelas IV tema bangga terhadap daerah tempat tinggalku. Dengan memberikan rumusan masalah bagaimana bentuk implementasi karakter mandiri siswa saat proses pembelajaran daring dengan memonitoring menggunakan basis media asinkronus.

\section{METODE PENELITIAN}

Pada metode penelitian ini yang digunakan adalah penelitian deskriptif dengan menggunakan pendekatan kuantitatif. Menurut (Sugiyono dalam Jayusman, 2020) deskriptif adalah penelitian yang digunakan untuk mengetahui beberapa variable yang kemudian akan dibandingkan ataupun dihubungkan. Sedangkan menurut (Jayusman \& Shavab, 2020) sendiri menyatakan bahwa penelitian deskirptif adalah berkaitan dengan realita dan gejala yang ada kemudian dijelaskan dan dijabarkan. Pendekatan penelitian ini yaitu menggunakan pendekatan kuantitatif. Menurut (Arikunto, 2012) kuantitatif adalah pengumpulan data dan penafsirannya menggunakan angka. Dengan menggunakan instrumen penilaian yaitu angket yang diberikan untuk orang tua. Teknik analisis data dengan menggunakan manual. Subjek penelitian terdapat pada siswa sekolah dasar SDN Mojoroto 4 Kota Kediri pada kelas IV A terdiri dari 15 siswa yang terdiri dari 7 siswa laki-laki dan 8 siswa perempuan. 


\section{HASIL DAN PEMBAHASAN}

Karakter peserta didik terdiri dari beberapa macam salah satunya yaitu karakter mandiri. Karakter mandiri siswa dapat dilihat dalam suatu prosess pembelajaran. Karakter tersebut dapat dilihat pada beberapa aktifitas fisik yang dapat dilihat secara langsung dalam proses pembelajaran. Namun dalam keadaan pandemi seperti ini yaitu menggunakan media daring untuk menunjang proses pembelajaran dapat melihat karakter siswa melalui diskusi berlangsung dengan menggunakan bantuan aplikasi online. Dengan melihat karakter siswa dapat diketahui dari keaktifan siswa sebenarnya, keaktifan tersebut dapat dilihat dan diamati oleh orang tua sehingga guru dapat mensurvei secara langsung kepada orang tua. Dapat diketahui bahwa keaktifan siswa sangat menentukan juga pada karakter siswa terutama karakter mandiri. Menurut Mulyasa dalam (Wibowo, 2016) bahwa pentingnya keaktifan siswa dalam pembelajaran dapat dikatakan berhasil dan berkualitas ketika adanya peserta didik yang berprilaku akti baik fisik maupun mental dan sosial saat proses pembelajaran.

Penelitian ini fokus pada keaktifan siswa yang terletak pada indikator karakter siswa diantaranya adalah bertanggung jawab, selalu tepat waktu dalam mengerjakan tugas/ulangan, semangat dalam mengikuti pembelajran, rajin dalam menyelesaikan ulangan atau tugas, membuat karya secara mandiri, berani bertanya saat pembelajaran, mengerjakan ulangan/tugas secara mandiri, selalu belajar walaupun saat pembelajaran daring. Berikut hasil dari penelitian karakter mandiri siswa:

Tabel 1: Nilai karakter mandiri siswa.

\begin{tabular}{|c|c|c|c|c|}
\hline No & Indikator karakter & Pilihan & $\begin{array}{l}\text { Banyak } \\
\text { siswa }\end{array}$ & Presentase \\
\hline \multirow[t]{4}{*}{1.} & \multirow{4}{*}{$\begin{array}{l}\text { Bertanggung } \\
\text { jawab }\end{array}$} & Sangat tanggung jawab & 9 & $60 \%$ \\
\hline & & $\begin{array}{lll}\begin{array}{l}\text { Tanggung } \\
\text { didampingi }\end{array} & \text { jawab } & \text { bila } \\
\end{array}$ & 4 & $26,6 \%$ \\
\hline & & Kurang tanggung jawab & 2 & $13,3 \%$ \\
\hline & & $\begin{array}{l}\text { Tidak tanggung jawab sama } \\
\text { sekali }\end{array}$ & 0 & $0 \%$ \\
\hline \multirow[t]{4}{*}{2.} & \multirow{4}{*}{$\begin{array}{l}\text { Selalu tepat waktu } \\
\text { dalam } \\
\text { mengerjakan dan } \\
\text { mengumpulkan } \\
\text { tugas/ulangan }\end{array}$} & Selalu tepat waktu & 9 & $60 \%$ \\
\hline & & Terlambat 1 kali & 3 & $20 \%$ \\
\hline & & Terlambat lebih dari 1 kali & 3 & $20 \%$ \\
\hline & & Terlambat lebih dari 5 & 0 & $0 \%$ \\
\hline \multirow[t]{4}{*}{3.} & \multirow{4}{*}{$\begin{array}{l}\text { Semangat dalam } \\
\text { mengikuti } \\
\text { pembelajaran }\end{array}$} & Selalu semangat & 10 & $66,6 \%$ \\
\hline & & Semangat bila didamping & 3 & $20 \%$ \\
\hline & & Terkadang semangat & 2 & $13,3 \%$ \\
\hline & & Tidak semangat sama sekali & 0 & $0 \%$ \\
\hline \multirow[t]{4}{*}{4.} & \multirow{4}{*}{$\begin{array}{l}\text { Rajin dalam } \\
\text { menyelesaikan } \\
\text { tugas atau ulangan }\end{array}$} & Sangat rajin & 1 & $6,66 \%$ \\
\hline & & Rajin & 14 & $93,3 \%$ \\
\hline & & Kurang rajin & 0 & $0 \%$ \\
\hline & & Tidak rajin sama sekali & 0 & $0 \%$ \\
\hline \multirow[t]{4}{*}{5.} & \multirow[t]{4}{*}{ 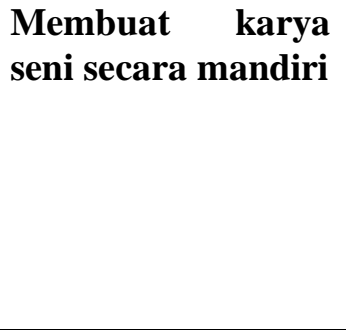 } & $\begin{array}{l}\text { Selalu membuat karya secara } \\
\text { mandiri }\end{array}$ & 3 & $20 \%$ \\
\hline & & $\begin{array}{l}\text { Terkadang dibimbing orang } \\
\text { tua }\end{array}$ & 11 & $73,3 \%$ \\
\hline & & Selalu dibimbing orangtua & 1 & $6,66 \%$ \\
\hline & & $\begin{array}{l}\text { Tidak pernah membuat karya } \\
\text { secara mandiri }\end{array}$ & 0 & $0 \%$ \\
\hline
\end{tabular}



Media Asinkronus - Tera Noviantiningtyas Ripto Saputri, Bagus Amirul Mukmin DOI: https://doi.org/10.31004/basicedu.v5i4.1126

\begin{tabular}{|c|c|c|c|c|}
\hline \multirow[t]{4}{*}{6.} & \multirow{4}{*}{$\begin{array}{l}\text { Berani bertanya } \\
\text { ketika } \\
\text { pembelajaran }\end{array}$} & Seringkali & 5 & $33,3 \%$ \\
\hline & & Terkadang & 10 & $66,6 \%$ \\
\hline & & Pernah walaupun sekali & 0 & $0 \%$ \\
\hline & & Tidak sama sekali & 0 & $0 \%$ \\
\hline \multirow[t]{4}{*}{7.} & \multirow{4}{*}{$\begin{array}{l}\text { Mengerjakan soal } \\
\text { tugas/tes secara } \\
\text { mandiri }\end{array}$} & Selalu mengerjakan sendiri & 4 & $26,6 \%$ \\
\hline & & $\begin{array}{l}\text { Terkadang, minta dibimbing } \\
\text { orangtua ataupun orang lain }\end{array}$ & 11 & $73,3 \%$ \\
\hline & & $\begin{array}{l}\text { Selalu, minta dibimbing } \\
\text { orangtua ataupun orang lain }\end{array}$ & 0 & $0 \%$ \\
\hline & & $\begin{array}{l}\text { Tidak pernah mengerjakan } \\
\text { secara mandiri sama sekali }\end{array}$ & 0 & $0 \%$ \\
\hline \multirow[t]{4}{*}{8.} & \multirow{4}{*}{$\begin{array}{l}\text { Selalu belajar } \\
\text { walaupun } \\
\text { pembelajaran } \\
\text { daring }\end{array}$} & Selalu belajar & 6 & $40 \%$ \\
\hline & & Terkadang belajar & 8 & $53,3 \%$ \\
\hline & & Belajar jika hanya ada tugas & 1 & $6,66 \%$ \\
\hline & & Tidak belajar sama sekali & 0 & $0 \%$ \\
\hline
\end{tabular}

\section{Bertanggung jawab}

Bertanggung jawab adalah karakter yang dimiliki siswa dengan selalu menanggung konsekuensi atas apa yang telah diputuskan untuk dikerjakan. Diperkuat menurut (Pramasanti et al., 2020) bahwa karakter bertanggung jawab selalu mengerjakan apa yang sudah menjadi tugasnya. Implementasi tanggung jawab dalam pembelajaran adalah siswa yang mampu mengerjakan tugas yang diberikan guru, mentaati peraturan ataupun jika adanya tidak mentaati maka mereka harus mampu menanggungjawabkan perilakunya atas sanksi yang diterima, dll. Karakter tanggung jawab pada penelitian ini mendapatkan hasil bahwa karakter siswa yang sangat bertanggung jawab dalam mengerjakan tugas atau ulangan yang diberikan oleh guru sebanyak 9 siswa atau $60 \%$, untuk siswa yang tanggung jawab apabila didampingi sebanyak 4 orang atau $26,6 \%$, kemudian siswa yang kurang tanggung jawab sebanyak 2 orang atau 13,3\%, dan siswa yang tidak tanggung jawab sama sekali sebanyak 0 orang atau $0 \%$. Dengan hasil yang didapat maka karakter siswa lebih dominan atau mayoritas pada siswa yang memiliki karakter sangat tanggung jawab apabila diberikan tugas ataupun ulangan yang diberikan oleh guru. dapat disimpulkan bahwa siswa kelas IV SDN Mojoroto 4 Kota Kediri ini banyak yang memilki karakter tanggung jawab walaupun pada saat pembelajaran secara daring. Diperkuat oleh (Syafi'ah \& Sari, 2020) bahwa SDN Tegalrejo Tulungagung juga memiliki sikap tanggung jawab ketika dimulai pembelajaran hingga selesai pembelajaran. Rasa tanggung jawab walaupun saat pembelajaran daring.

\section{Tepat waktu dalam mengerjakan tugas/ulangan}

Tepat waktu dalam mengerjakan tugas juga merupakan bentuk kemandirian siswa dengan melibatkan semangat dalam diri untuk mengerjakan apa yang seharusnya menjadi tanggung jawab siswa untuk menegrjakan tugasulangan tanpa disuruh. Kemudian dalam mengumpulkan tugas yang diberikan oleh guru, siswa selalu mengumpulkan secara minimal tepat waktu, bahkan sebelum waktunya pengumpulan justru lebih baik asalkan tidak melampaui tenggat yang diberikan. Pengumpulan tugas dikumpukan melalui media asinkronus seperti whatsaap, atau google formulir. Dengan angket yang diberikan, hasil yang diperoleh pada peneitian ini adalah siswa yang selalu tepat waktu dalam mengumpulkan tugas adalah sebanyak 9 orang atau $60 \%$, siswa yang mengumpulkan tugas terlambat 1 kali sebanyak 3 orang atau $20 \%$, kemudian siswa yang mengumpulkan terlambat sebanyak lebih dari 1 kali adalah 3 irang atau 20\%, dan siswa yang terlambat lebih dari 5 kali tidak ada. Dapat disimpulkan bahwa saat pembelajaran daring kelas IV SDN Mojoroto 4 Kota Kediri mengumpulkan tepat waktu dalam pengumpulan tugas atau ulangan pada media asinkronus sebagai 
tempat pengumpulan tugas. Diperkuat dengan hasil penelitian (Sucipto, 2017) bahwa siswa yang tepat waktu dalam mengumpulkan tugas dengan tepat waktu sebanyak 91,67\%.

\section{Semangat dalam mengikuti pembelajran,}

Karakter semangat akan tumbuh pada siswa yang memiliki jiwa pantang menyerah dan selalu ingin tahu serta terus berjuang untuk mendapatkan hasil yang terbaik. Karakter semangat timbul karena adanya dorongan atau termotivasi terhadap sekelilingnya baik dari lingkungan keluarga maupun masyarakat. Diperkuat dengan (Rudini \& Agustina, 2021) bahwa motivasi yang diberikan akan timbul dalam bentuk perilaku yang siap bergerak dan berusaha dalam mengerjakan sesuatu termasuk dalam aktivitas belajar. Dalam penelitian ini sikap semangat yang timbul pada siswa saat pembelajaran daring dalam mengikuti pembelajaran adalah siswa yang selalu semangat sebanyak 10 orang atau $66,6 \%$, siswa yang semangat apabila didampingi sebanyak 3 orang, siswa yang terkadang semangat sebanyak 2 orang atau 13,3\%, dan siswa yang tidak memiliki semangat sama sekali adalah tidak ada. Dapat disimpulkan bahwa siswa saat pembelajaran daring mayoritas semangat semua dalam mengikutinya.

\section{Rajin dalam menyelesaikan ulangan atau tugas}

Karakter mandiri dalam indikator rajin pada manusia sering kita jumpai ketika waktu pembelajaran seperti selalu mengerjakan tugas yang diberikan oleh guru. Rajin adalah suatu karakter atau kebiasaan yang memiliki pola tingkah laku dengan niat yang tekun dan selalu berusaha untuk mencapai suatu tujuan tertentu. Diperkuat dengan pernyatan (Maspupah, 2018) bahwa siswa yang memiliki sifat rajin dapat mengerjakan tugas yang diberikan oleh guru dengan semaksimal mungkin dan langsung dikerjakan. Dari angket yang diberikan untuk wali murid agar terlihatnya kolaborasi antara guru dan orang tuas, maka didapatkan bahwa siswa yang sangat rajin saat pembelajaran selama pandemic sebanyak 1 orang atau 6,66\%, dan siswa yang rajin sebanyak 14 orang atau 93,3\%, kemudian untuk siswa yang kurang rajin atau tidak rajin sama sekali sebanyak 0 orang atau tidak ada. Dampak Pekerjaan

\section{Membuat karya secara mandiri}

Kreatifitas siswa dapat dilihat dari cara mereka untuk membuat karya secara mandiri, baik dari seni rupa atau seni lainnya melalui pendidikan seni rupa atau lainnya. Menurut Dari angket yang diberikan, dapat diperoleh siswa yang selalu membuat karya sendiri sebanyak 3 orang atau 20\%, siswa yang membuat karya namun masih dibimbing oleh orang tua sebanyak 11 orang atau $73,3 \%$, siswa yang selalu dibimbing oleh orang tua sebanyak 1 orang saja atau $6,66 \%$, dan siswa yang tidak mampu membuat karya sendiri sebanyak 0 orang atau tidak ada. Diperkuat dengan menurut (Rofian, 2016) bahwa siswa dapat memahami karya seni dengan melihat proses dari awal yang diberikan contoh oleh guru, kemudian siswa mencobanya.

\section{Berani bertanya saat pembelajaran}

Berani dalam bertanya saat pembelajaran merupakan salah satu bentuk keaktifan siswa yang timbul karena adanya karakter yang sudah tertanam pada diri siswa. Sifat keberanian selalu muncul dan seimbang dengan karakter percaya diri. Apabila percaya dirinya siswa tinggi maka merekapun dapat memberikan opini saat pembelajaran baik dalam kegiatan bertanya atau menjawab maupun dalam kegiatan memberikan pendapat dari evaluasi pembelajaran ataupun kesimpulan materi. Menurut (Lestari, 2015) bahwa berani dalam bertanya adalah kegiatan yang timbul dari karakter siswa dalam setiap individu yang mampu menampilkan kemampuan dengan adanya rasa percaya diri dalam mengatasi rasa takut untuk berani mencoba dalam memberikan jawaban atau menanyakan jawaban. Dari angket yang diberikan dapat diperoleh bahwa siswa yang seringkali dalam berani berkomunikasi saat pembelajaran sebanyak 5 orang atau 33,3\%, siswa yang 
terkadang berani berkomunikasi sebnayak 10 orang atau $66,6 \%$, kemudian siswa yang pernah walaupun sekali dan tidak sama sekali sebanyak 0 orang atau tidak ada.

\section{Mengerjakan ulangan/tugas secara mandiri}

Di dalam pembelajaran guru memberikan ualangan atau tugas adalah hal yang wajar. Namun dalam segi ini yang harus diperhatikan adalah siswa yang mengerjakan tugas tersebut dengan mandiri atau tidak. Terkadang siswa ada yang tidak dapat mengerjakan secara mandiri sehinga mereka selalu bertanya kepada teman atau yang lainnya sehingga dapat menimbulkan karakter atau kebiasaan yang tidak baik seperti timbulnya kecurangan. Diperkuat dnegan pendapat (Fitriyani et al., 2020) bahwa sikap kemandirian siswa dapat dilihat dalam pengerjaan siswa yang dikerjakan degan cukup baik. pada SDN Mojoroto 4 Kota Kediri ini menghasilkan bahwa siswa yang sellau mengerjakan tugas secara mandiri sebanyka 4 orang atau 26,6\%, siswa yang terkadang mengerjakan secara mandiri dan minta dibimbing orangtua ataupun orang lain sebanyak 11 orang atau $73,3 \%$, dan siswa yang selalu meminta bimbingan orang tua dan tidak pernah mengerjakan secara mandiri sebanyak 0 orang atau tidak ada. Seperti pada penelitian (Fitriyani et al., 2020) bahwa karakter mandiri siswa memperoleh hasil 80,75\% yang menunjukan kriteria sangat baik dalam pengerjaan siswa saat pembelajaran secara daring.

\section{Selalu belajar walaupun saat pembelajaran daring.}

Belajar adalah kegiatan yang wajib kita lakukan sebagai pelajar, untuk menambah ilmu dan wawasan kita dalam menghadapi tantangan untuk menyelesaikannya. Menurut (Santoso \& Subagyo, 2017) bahwa belajar adalah perubahan dari tingkah laku berdasarkan pengalaman dan pemahaman yang dimilikinya. Namun saat pandemic kegiatan belajar harus dituntut dengan insiatif mandiri agar tetap melaksanakan kegiatan belajar dengan niat untuk untuk menambah pengetahuan dan tentunya tidak kalah dengan temannya, minimal nilainya tidak turun. Berdasarkan angket yang diberikan kepada orang tua untuk mengawasi anaknya. Dihasilkan bahwa siswa yang selalu belajar di rumah sebanyak 6 orang atau 40\%, siswa yang terkadang belajar sebanyak 8 orang atau 53,3\%, dan siswa yang belajar jika hanya ada tugas sebanyak 1 orang atau $6,66 \%$, kemudian siswa yang sama sekali tidak belajar sebanyak $0 \%$ atau tidak ada.

\section{KESIMPULAN}

Monitoring karakter siswa melalui kerjasama dengan orang tua dengan melihat pembelajaran berbasis media asinkronus. Memperoleh hasil bahwa selama pembelajaran daring banyak siswa yang sangat tanggung jawab terhadap pembelajaran dengan sebanyak 9 orang atau $60 \%$, kemudian siswa yang selalu tepat waktu dalam mengumpulkan dan mengerjakan tugas atau ulangan lebih dominan banyak siswa yang tepat waktu dengan banyaknya siswa sebanyak 9 orang atau 60\%, siswa yang semangat dalam mengikuti pembelajaran walaupun saat pembelajaran daring lebih dominan banyak siswa yang selalu semangat sebanyak $10 \%$ atau $66,6 \%$, kemudian siswa yang selalu rajin dalam menyelesaikan tugas atau ulangan lebih dominan siswa yang hanya rajin sebnayak $14 \%$ atau $93,3 \%$, kemudian siswa yang mampu membuat karya secara mandiri lebih banyak siswa yang terkadang dibimbing orang tua dalam mengerjakan sebanyak 11 orang atau 73,3\%, siswa yang berani bertanya ketika pembelajaran lebih banyak kriteria terkadang dalam bertanya saat pembelajaran sebanyak 10 0rang siswa atau 66,6\%, kemudian siswa yang mengerjakan tugas/ulangan secara mandiri lebih dominan dalam kriteria terkadang minta bimbingan orang tua atau orang lain sebanyak 11 orang atau 73,3\%, dan yang terakhir pada indikator sisa yang selalu belajar pada saat pembelajaran lebih banyak pada kriteria siswa yang terkadang belajar sebanyak siswa 8 orang atau 53,3\%. 
2052 Analisis Implementasi Karakter Mandiri Siswa Sekolah Dasar di Masa Pandemi Covid-19 Berbasis Media Asinkronus - Tera Noviantiningtyas Ripto Saputri, Bagus Amirul Mukmin

DOI: https://doi.org/10.31004/basicedu.v5i4.1126

\section{UCAPAN TERIMA KASIH}

Terima kasih kepada dosen pembimbing yang telah membimbing dalam penulisan penelitian ini. Terima kasih kepada guru SDN Mojoroto 4 Kota Kediri yang telah bersedia membantu untuk melakukan penelitian. Terima kasih kepada pihak yang telah mendukung baik materil maupun non materil sehingga penulisan ini berjalan dengan lancer. Semoga penulisan ini menjadi berkah dan bermanfaat.

\section{DAFTAR PUSTAKA}

Anugrahana, A. (2020). Hambatan, Solusi Dan Harapan: Pembelajaran Daring Selama Masa Pandemi Covid19 Oleh Guru Sekolah Dasar. Scholaria: Jurnal Pendidikan Dan Kebudayaan, 10(3), 282-289.

Arikunto, S. (2012). Prosedur Penelitian Suatu Pendekatan Praktek. Rineka Cipta.

Arsyad, A. (2011). Media Pembelajaran. Jakarta: PT Raja Grafindo Persada.

Daheri, M., Juliana, J., Deriwanto, D., \& Amda, A. D. (2020). Efektifitas Whatsapp Sebagai Media Belajar Daring. Jurnal Basicedu, 4(4), 775-783.

Fahmi, M. H. (2020). Komunikasi Synchronous Dan Asynchronous Dalam E-Learning Pada Masa Pandemic Covid-19. Jurnal Nomosleca, 6(2). Https://Doi.Org/10.26905/Nomosleca.V6i2.4947

Faqih, F. I. (2019). Pembentukan Karakter Peserta Didik Melalui Sosiodrama. Jurnal Pendidikan Bahasa Dan Sastra Indonesia Metalingua, 4(1), 13-18.

Fitriyani, Y., Fauzi, I., \& Sari, M. Z. (2020). Motivasi Belajar Mahasiswa Pada Pembelajaran Daring Selama Pandemik Covid-19. Jurnal Kependidikan: Jurnal Hasil Penelitian Dan Kajian Kepustakaan Di Bidang Pendidikan, Pengajaran Dan Pembelajaran, 6(2), 165-175.

Handarini, O. I., \& Wulandari, S. S. (2020). Pembelajaran Daring Sebagai Upaya Study From Home (SFH) Selama Pandemi Covid 19. Jurnal Pendidikan Administrasi Perkantoran (JPAP), 8(3), 496-503.

Jayusman, I., \& Shavab, O. A. K. (2020). Aktivitas Belajar Mahasiswa Dengan Menggunakan Media Pembelajaran Learning Management System (Lms) Berbasis Edmodo Dalam Pembelajaran Sejarah. Jurnal Artefak, 7(1), 13-20. Http://Dx.Doi.Org/10.25157/Ja.V7i1.3180

Lestari, D. A. (2015). Pendekatan Saintifik Dalam Pembelajaran Tematik Untuk Meningkatkan Ketrampilan Bertanya Siswa. Widyagogik: Jurnal Pendidikan Dan Pembelajaran Sekolah Dasar, 3(1), 66-78.

Maspupah, S. A. N. H. (2018). Orang Tua Pada Semangat Belajar Siswa MA Hasan Muchyi Kelas XI D [Phd Thesis]. IAIN Kediri.

Oviana, W. O. (2020). Kemampuan Guru IPA Dalam Menumbuhkan Nilai Karakter Siswa Pada MTSN Di Aceh. Jurnal Ilmiah Didaktika: Media Ilmiah Pendidikan Dan Pengajaran, 20(2), 189-200. Http://Dx.Doi.Org/10.22373/Jid.V20i2.4981

Pramasanti, R., Bramasta, D., \& Anggoro, S. (2020). Implementasi Pendidikan Karakter Tanggung Jawab Dan Kerja Sama Dalam Pembelajaran Tematik Kurikulum 2013 Di SD Negeri 2 Berkoh. Jurnal Papeda: Jurnal Publikasi Pendidikan Dasar, 2(1), 43-48.

Rofian, R. (2016). Penerapan Metode Pembelajaran Demostrasi Pada Pendidikan Seni Rupa Di Sekolah Dasar. Malih Peddas (Majalah Ilmiah Pendidikan Dasar), 6(2).

Rudini, M., \& Agustina, A. (2021). Analisis Motivasi Siswa Dalam Mengerjakan Tugas Rumah Di SMA AlMannan Tolitoli. Jurnal Cendekia: Jurnal Pendidikan Matematika, 5(1), 770-780.

Sadikin, A., \& Hamidah, A. (2020). Pembelajaran Daring Di Tengah Wabah Covid-19:(Online Learning In The Middle Of The Covid-19 Pandemic). Biodik, 6(2), 214-224. Https://Doi.Org/10.22437/Bio.V6i2.9759

Sakti, B. P. (2018). Indikator Pengembangan Karakter Siswa Sekolah Dasar. INA-Rxiv. 
2053 Analisis Implementasi Karakter Mandiri Siswa Sekolah Dasar di Masa Pandemi Covid-19 Berbasis Media Asinkronus - Tera Noviantiningtyas Ripto Saputri, Bagus Amirul Mukmin

DOI: https://doi.org/10.31004/basicedu.v5i4.1126

Santoso, H. B., \& Subagyo, S. (2017). Peningkatan Aktifitas Dan Hasil Belajar Dengan Metode Problem Basic Learning (PBL) Pada Mata Pelajaran Tune Up Motor Bensin Siswa Kelas XI Di SMK Insan Cendekia Turi Sleman Tahun Ajaran 2015/2016. Jurnal Taman Vokasi, 5(1), 40-45.

Sucipto, W. T. (2017). Peningkatan Aktivitas Belajar Dan Kemampuan Memahami Unsur Intrinsik Cerpen Dalam Pembelajaran Bahasa Indonesia Melalui Metode Pembelajaran Kooperatif Model Two Stay Two Stray Pada Siswa Kelas IX A SMP Murni 1 Surakarta Semester 1 Tahun Pelajaran 2016/2017.

Syafi'ah, R., \& Sari, W. (2020). Analisis Sikap Tanggung Jawab Siswa Dalam Proses Pembelajaran Daring Melalui Aplikasi Whatsapp. At-Thullab: Jurnal Pendidikan Guru Madrasah Ibtidaiyah, 4(2), 111-118.

Wibowo, N. (2016). Upaya Peningkatan Keaktifan Siswa Melalui Pembelajaran Berdasarkan Gaya Belajar Di SMK Negeri 1 Saptosari. Elinvo (Electronics, Informatics, And Vocational Education), 1(2), 128-139. Https://Doi.Org/(Wibowo, 2016) 